\title{
Nesting Preferences of Birds in Relation to Exotic Trees in Ludhiana, Punjab
}

\author{
Manpreet Kaur and Manoj Kumar* \\ Department of Zoology, Punjab Agricultural University, Ludhiana, Punjab, INDIA \\ "Corresponding author: M Kumar; E-mail: mansnr@pau.edu
}

Received: 19 Oct., $2019 \quad$ Revised: 20 Dec., $2019 \quad$ Accepted: 29 Dec., 2019

\begin{abstract}
Birds have very close association with trees. Trees offer a platform to birds for nesting, roosting, foraging, breeding and feeding purposes. The introduction of exotic (non-native) flora can effect or modify inherent species richness, communal alignment and species abundance, as well as species relationships and communal structure. Birds are exclusively sensitive to alterations both in terms of environmental and ecological. Introduction of exotic trees and human disturbance have also affected the bird diversity. The main objective of the present study was to find out the nesting preference of avian species in relation to exotic trees at two selected locations i.e. Punjab Agricultural University, Ludhiana (Location I) and Gurpal Nagar, Ludhiana (Location II) from June 2018 to July 2019. Five different exotic trees species selected were Safeda (Eucalyptus tereticornis), Poplar (Populus deltoides), Bottle brush (Callistemon viminalis), Monkey Puzzle (Araucaria araucana), Silver Oak (Grivillea robusta). A total 31 nests ( 6 on Bottle brush tree, 2 on Silver oak tree, 7 on Poplar tree, 16 on Eucalyptus tree) were recorded. Out of these, 5 nests were of Baya weaver Ploceus philippinus, 4 nests were of Rose-ringed Parakeet Psittacula krameri, 20 nests were of House Crow Corvus splendens and 2 nests were of Common Myna Acridotheres tristis. Four bird species were observed nesting at location I while only one was observed at location II. Less bird diversity recorded was at location II (8) as compared to location I (23) because of the anthropogenic activities which disturbed the natural habitat at that location.
\end{abstract}

Keywords: Bird species, nesting, exotic trees, nesting preference

Birds have very close association with trees. There is a complicated connection that is present between birds and trees. There are number of variables in a habitat such as vegetation cover, foliage height and these variables influence avian abundance and diversity. Birds need nests for incubation purposes, to raise young ones during breeding period, to hold eggs so nests act as a platform. Birds are near-ubiquitous, mobile, and approachable at fine progressive scales. Avian protection and management contains a considerate of bird-habitat associations. Birds vary a lot from one another in most of their existence configuration like habitation, nutrition, pigmentation, size, feathers pattern, dispersal etc. Similarly nests of birds are also having enormous distinctions in their size, shape, organization, material used, construction pattern, selection of site for nest and nest construction (Vyas, 2009).

Birds are vital and economically important as they provide ecosystem services such as pollination, seed dispersal in addition to recreation value provided by them (Sekercioglu, 2006; Whelan et al., 2015). Although Egrets, Herons, Water Hens are aquatic birds inhabiting water bodies for their food requirements but for nesting purposes they prefer trees (Sandhu, 1993). Forest provides many ecosystem services (Shvidenko et al., 2005). The alteration from native to exotic streetscapes saw the liberal damage of insectivorous and nectarivorous bird types reflecting a faith by these species on structurally varied and/or native vegetation for both shelter and food resources (Antos et al., 2003).

Bird community study undertaken at campus of Punjab Agricultural University, Ludhiana by choosing different tree species i.e. Eucalyptus globulus, grape (Vitis vinifera), sarin (Albizzia stipulata), lemon (Citrus limon), mango

How to cite this article: Kaur, M. and Kumar, M. (2020). Nesting preferences of birds in relation to exotic trees in Ludhiana, Punjab. J. Anim. Res., 10(1): 105-109. 
(Mangifera indica), dek (Melia azedarach), orange (Citrus sinesis), grapefruit (Citrus paradise), neem (Azdirachta indica) and simbal (Bombax malabaricum) revealed a total of 12 species of birds (Malhi and Kler 1999). Bird species that constituted the major bulk of community structure are House Crow, Common Myna, Common Babbler while Black Drongo, Cattle Egret, Red-vented Bulbul and Redwattled Lapwing constituted minor component on fruit and woody trees.

In India agricultural lands such as agricultural field areas of Punjab that are widely cultivated have vast varieties of dairy, poultry, honeybee farms distributed between crop fields. Various kinds of native and exotic agro-forestry trees present along these farms and with these forests they also fulfil food requirements of birds in form of berries, nectar, fruits of trees, seeds etc. In agronomy double role of birds is well known (Ali, 1971). There are number of exotic trees that are being introduced in our country. Eucalyptus, Pines, Poplars are exotic species and are fast growing tree species in the world over. It is estimated that approximately 4.8 mha of Eucalyptus and 60,000 ha of Populus sps. is growing in India alone (Chandra, 2001).

The environmental influence of introduced plant occupation are recorded everywhere in addition to complexity of biological networks, ecosystem diversity, taxa, spatial and temporal scales (Vila et al., 2011; Pysek et al., 2012; Schirmel et al., 2016).

Study has revealed that Eucalyptus farms have a lesser number of animals species (Barlow et al., 2007; Proença et al., 2010; Calviño-Cancela et al., 2012) and bird species (Bongiorno,1982; Pina, 1989; Tellería and Galarza ,1990; Barlow et al., 2007; Proença et al., 2010; CalviñoCancela, 2013; De la Hera et al., 2013), related to innate plantations. Allowing other varied plantations could lessen bird biodiversity damage (Calviño-Cancela, 2013), even though it would never exchange native forest habitations and their biodiversity abundance but nesting sites and food availability increases by increasing types of plantations.

Alterations in communal difference can in turn be explained by evaluating species incomings (Baselga et al., 2007). Species species interaction (nestedness) occurs when species accumulations in sites with fewer species are subdivisions of species accumulations at richer sites (Ulrich and Gotelli, 2007). Nest has been well-defined as a structure that supports the growth of the eggs and the existence of young (Collias and Collias, 1964). In distinction, spatial turnover suggests an organized replacement of some species by others, as a concern of ecological arrangement and old restraints (Qian et al., 2005).

\section{MATERIALS AND METHODS}

The study was carried out from June 2018 to July 2019 to find out the nesting of avian species in relation to exotic trees. The study was carried out at selected locations i.e. Location 1: Punjab Agricultural University, Ludhiana $\left(75.79^{\circ} \mathrm{E}, 30.90^{\circ} \mathrm{N}\right.$, above mean sea level $\left.-189 \mathrm{~m}\right)$. Punjab Agricultural University site comprises of agronomic grounds, plantations, official campuses and housing areas. Location 2: Gurpal Nagar $\left(30.8764^{\circ} \mathrm{N}, 75.8770^{\circ} \mathrm{E}\right)$ Ludhiana. This area consists of residential area comprising of modern housing structure, Anaj Mandi, Canal, Schools, Parks, Hospitals (SPS Hospital) and Industries. Vegetation structure includes both indigenous trees and exotic trees. To study the nesting of bird species on five selected exotic tree species i.e. Safeda (Eucalyptus tereticornis), Silver Oak (Grevillea robusta), Poplar (Populus deltoides), The Monkey Puzzle (Araucaria araucana) and Bottle Brush (Callistemon viminalis). These exotic tree species are indigenous to Australia. Three trees for each species were selected at different sites. Safeda is known to be one of the tallest trees in the world attaining height of $65 \mathrm{~m}$. The Silver Oak is an evergreen large tree attaining a height of $30-35 \mathrm{~m}$. Poplar is a fast growing tall tree attaining a height of $30 \mathrm{~m}$. The Monkey Puzzle is an evergreen tree growing to $1-1.5 \mathrm{~m}$ in diameter and $30-40 \mathrm{~m}$ in height. Bottle Brush is a small tree upto $8 \mathrm{~m}$ tall although large specimens up to $18 \mathrm{~m}$ tall have also been recorded. Periodic surveys were carried out by adopting systematic field procedures techniques and point count methods was followed at selected sites (Javed and Kaul, 2002). Identification of birds was done with the help of key given by Ali (Ali, 2002) and nomenclature given by Manakadan and Pittie (2001) was followed. Nesting parameter like nest height, type of tree utilized for nesting, nest location, tree height along with nesting material used were recorded. Instrument used for the observations were Digital camera (Nikon P 500), Bushnell Binocular $(8 \times 42)$ for observing birds and Haglöf EC II Clinometer for measuring tree height. 


\section{RESULTS AND DISCUSSION}

A total 31 nests (Two on The Silver oak tree, seven on Poplar tree, sixteen on Eucalyptus tree \& six on Bottle brush tree) were recorded. Out of these, five nests were of Baya weaver Ploceus philippinus, four nests were of Rose-ringed Parakeet Psittacula krameri, twenty nests were of House Crow Corvus splendens and two nests were of Common Myna Acridotheres tristis (Table 1). Four bird species were recorded to utilize five selected trees for nesting (Table 1).

Rose-ringed parakeets and Common Myna used cavities available on Eucalyptus and The Silver oak trees for nesting. Small birds like Baya weaver birds preferred trees with less height i.e. Bottle brush tree. House Crow is adaptable to all types of vegetation. Trees with great height and dense foliage are preferred by large birds for nesting. House Crow nests were found greater in number on Eucalyptus, Poplar, Bottle brush (Abandoned) trees. Successful nesting of House Crow was observed mainly on Eucalyptus and Poplar. During the study it was observed that Monkey puzzle tree was not utilised by any bird species for nesting.

\section{Nesting at location I}

Nesting of Baya weaver birds were observed from first week of June on Bottle brush tree. Five nests were observed and were made up of rough edged grasses but they were not completely formed. Later on the nests were abandoned. Only one nest of House Crow was observed on Bottle brush tree by second week of June. The nest was made up of dry sticks but after construction of nest bird was not observed near the nest and it was abandoned. In the Silver oak tree, two nests of Rose-ringed Parakeet were observed in already existing cavities from second week of November. On Poplar tree House Crow nesting was recorded from third week of June. The nest was made up of dry sticks, rags and twigs and nesting activities were continued till August. Total seven nests were observed on Poplar tree. Nesting of House Crow was found on Eucalyptus tree from Second week of June and it continue till August. Number of nests found in Eucalyptus trees was fourteen. Two nests of Rose-ringed parakeet was found on Eucalyptus tree in an already existing cavity from first week of June but nesting was not successfully completed. Similar observation in relation to tree preferences were

Table 1: Observations on the nesting of birds on selected tree species

\begin{tabular}{|c|c|c|c|c|c|c|c|c|}
\hline Tree & Locations & Bird & $\begin{array}{l}\text { Tree height } \\
\text { (m) }\end{array}$ & $\begin{array}{l}\text { Number of } \\
\text { nests }\end{array}$ & $\begin{array}{l}\text { Nest height } \\
\text { (m) }\end{array}$ & Initiation of nesting & Nesting material & Nest status \\
\hline Monkey & I & - & 9 & & - & - & - & - \\
\hline Puzzle & II & - & 8 & & - & - & - & - \\
\hline \multirow{3}{*}{$\begin{array}{l}\text { Bottle } \\
\text { brush }\end{array}$} & \multirow[t]{2}{*}{ I } & Baya weaver & 12 & 5 & $3-3.5$ & First week of June & $\begin{array}{l}\text { Rough edged } \\
\text { grasses }\end{array}$ & Abandoned \\
\hline & & House Crow & & 1 & 7 & $\begin{array}{l}\text { Second week of } \\
\text { June }\end{array}$ & Dry sticks & Abandoned \\
\hline & II & - & 10 & - & - & - & - & - \\
\hline \multirow{2}{*}{$\begin{array}{c}\text { The Silver } \\
\text { Oak }\end{array}$} & I & $\begin{array}{l}\text { Rose-ringed } \\
\text { Parakeet }\end{array}$ & 35 & 2 & $24-30$ & $\begin{array}{l}\text { Second week of } \\
\text { November }\end{array}$ & Cavity & $\begin{array}{l}\text { No information } \\
\text { available }\end{array}$ \\
\hline & II & - & 28 & - & - & - & - & - \\
\hline \multirow[t]{2}{*}{ Poplar } & I & House Crow & 43 & 7 & $39-40$ & Third week of June & $\begin{array}{l}\text { Dry sticks, rags } \\
\text { and twigs }\end{array}$ & $\begin{array}{l}\text { Continue till } \\
\text { August }\end{array}$ \\
\hline & II & - & 40 & - & - & - & - & - \\
\hline \multirow{4}{*}{ Eucalyptus } & \multirow{3}{*}{ I } & House Crow & 45 & 10 & $35-40$ & $\begin{array}{l}\text { Second week of } \\
\text { June }\end{array}$ & $\begin{array}{l}\text { Dry sticks, rags } \\
\text { and twigs }\end{array}$ & $\begin{array}{l}\text { Continue till } \\
\text { August }\end{array}$ \\
\hline & & $\begin{array}{l}\text { Rose-ringed } \\
\text { Parakeet }\end{array}$ & 45 & 2 & $38-42$ & First week of June & Cavity & Abandoned \\
\hline & & $\begin{array}{l}\text { Common } \\
\text { Myna }\end{array}$ & 45 & 2 & $40-41$ & $\begin{array}{l}\text { Second week of } \\
\text { January }\end{array}$ & Cavity & Abandoned \\
\hline & II & House Crow & 45 & 2 & $35-41$ & First week of June & $\begin{array}{l}\text { Dry sticks, twigs } \\
\text { and rags }\end{array}$ & $\begin{array}{l}\text { Continue till } \\
\text { August }\end{array}$ \\
\hline
\end{tabular}


also made by other workers (Natarajan, 1997; Ali, 2002; Kaur and Kumar, 2018; Kler et al., 2015). Parakeet is common bird that favours on the way to living in bulky and old vegetation (Prajapati and Prajapati, 2012). Parakeets pass entire daytime for the hunt of nourishing and searching however at sunset, they come back to branches for roosting, lodging and supervisory care of their families. Rose-ringed Parakeet is widespread in Punjab, its populace is growing due to the accessibility of perch openings in old trees nearby water canal banks and plain agronomic fields that offer them food and housing (Kler and Kumar, 2015).

Nesting of Common Myna was found on Eucalyptus tree from second week of January in two already existing cavities. Further no information available.

\section{Nesting at location II}

Only House Crow nesting was observed at location II and two nests were recorded on Eucalyptus tree from first week of June and it continues till August. Nesting material was dry sticks, twigs and rags as also observed in the nests of location I as also reported by Kaur and Kumar (2015). Similar observation regarding the nesting tree preferences were also reported by other workers (Kaur et al., 2015; Kaur and Kumar, 2018; Sethi and Kumar, 2018).

Trees with great height and dense foliage are preferred by large birds for nesting. House Crow nests were found greater in number on Eucalyptus, Poplar, Bottle brush trees. Successful nesting of House Crow was observed mainly on Eucalyptus and Poplar. House Crow was observed to utilize three out of five tree species under study for nesting purposes. Distribution of avian fauna affected by the depletion of indigenous trees and invasion of exotic trees. A local and regional survey was conducted to study bird community in Pinus $s p$. and Araucaria tree species. It was found that bird species richness was 50\% less in plantations than in native forests. Pine and Araucaria have same composition and species richness. Comparison showed greater species richness in native forests than in conifer plantations. It is estimated that threatened species only found on Araucaria forests. In the local and regional surveys a total of 124 species was recorded, 102 species was recorded in native forests and 73 in commercial plantations including 54 in Araucaria and 58 in Pine plantations (Zurita et al., 2006). More services provided by indigenous trees so there is need to promote indigenous trees over exotic trees.

\section{CONCLUSION}

A total of 4 bird species i.e. Baya weaver bird, Roseringed Parakeet, Common Myna and House Crow were recorded to make nest on five selected trees. A total of 31 nests (were recorded. Birds like Rose-ringed parakeets and Common Myna used cavities of Eucalyptus trees and The Silver oak for nesting. Small birds like Baya weaver birds preferred trees with less height i.e. Bottle brush tree. During the study it was observed that Monkey puzzle tree was not utilized by any bird species it may be due to the rough texture of leaves as well as tree surface and peculiar branching pattern of the tree which make it unsuitable for nesting by the birds. Dense canopies, cavities of old and native trees found to be an essential substrate for nesting. Services provided by indigenous trees are already a part of local ecology so there is need to promote plantation of indigenous trees over exotic trees.

\section{Acknowledgements}

Authors are grateful to Prof. \& Head, Department of Zoology, Punjab Agricultural University, Ludhiana for providing necessary facilities.

\section{REFERENCES}

Ali, S. 1971. Sunder Lal Hora memorial lecture. Ornithology in India: its past, present and future. Proc. Indian Natl. Sci. Acad., 37: 99-113.

Ali, S. 2002. The book of Indian birds. Oxford University Press, Bombay. Ann. Zool. Fenn., 26: 287-290.

Antos, J.M., Fitzsimons, A.J., Palmer, C.G. and White, G.J. 2003. Non-uniform bird assemblages in urban environments: the influence of streetscape vegetation. Landscape and Urban Planning, 71: 123-35.

Barlow, J., Gardner, T.A.,Araujo, I.S., Ávila-Pires, T.C., Bonaldo, A.B., Costa, J.E., Esposito, M.C., Ferreira, L.V., Hawes, J., Hernandez, M.I.M., Hoogmoed, M.S., Leite, R.N., Lo-Man-Hung, N.F., Malcolm, J.R., Martins, M.B., Mestre, L.A.M., Miranda-Santos, R., Nunes-Gutjahr, A.L., Overal, W.L., Parry, L., Peters, S.L., Ribeiro-Junior, M.A., da Silva, M.N.F., da Silva Motta, C. and Peres, C.A. 2007. Quantifying the biodiversity value of tropical primary, secondary, and plantation forests. Proc. Natl. Acad. Sci. USA., 104: 1855518560 . 
Baselga, A., Jiménez-Valverde, A. and Niccolini, G. 2007. A multiple-site similarity measure independent of richness. Biol. Lett., 3: 642-645.

Bongiorno, S.F. 1982. Land use and summer bird populations in northwestern Galicia, Spain. Ibis, 124: 1-20.

Calviño-Cancela, M. 2013. Effectiveness of eucalypt plantations as a surrogate habitat for birds. For. Ecol. Manag., 310: 692699.

Calviño-Cancela, M., Rubido-Bará, M. and Van Etten, E.J. 2012. Do eucalypt plantations provide habitat for native forest biodiversity? For. Ecol. Manag., 270: 153-162.

Chandra, J.P. 2001. Scope of poplar cultivation. Indian Forester, 127: 51-60.

De la Hera, I., Arizaga, J., Galarza, A. 2013. Exotic tree plantations and avian conservation in Northern Iberia: a view from a nest-box monitoring study. Anim. Biodivers. Conserv., 36: 153-163.

Javed, S. and Kaul, R., 2002. Field Methods for Bird Surveys. Bombay Natural History Society; Department of Wildlife Sciences, Aligarh Muslim University, Aligarh and World Pheasant Association, South Asia Regional Office (SARO), New Delhi, India.

Kaur, G., Kumar, M. and Kler, T.K. 2015. Nesting behavior of House Crow in agricultural areas of Ludhiana, Punjab. Ind. J. Appl. Res., 5(2): 770-71.

Kaur, N. and Kumar, M. 2018. Nesting of avian diversity in relation to indigenous trees. J. Ento. Zoo. Stud., 6(2): 422-436.

Kler, T.K. and Kumar, M. 2015. Prevalence of bird species in relation to food habits and habitat. Agri. Res. J., 52(1): 50-53.

Kler, T.K., Vashishat, N. and Kumar, M. 2015. Bird composition in urban landscape of Punjab. Int. J. Adv. Res., 3(5): 1113-18.

Malhi, C.S. and Kaur, T. 1999. On bird community structures of different trees. Tigerpaper, 26: 29-31.

Manakadan, R. and Pittie, A. 2001. Standardised common and scientific names of the birds of the Indian subcontinent. Buceros, 6(1): 1-38.

Natarajan, V. 1997. Breeding biology of the Southern CrowPheasant Centropus sinensis parroti Stresemann (Aves: Cuculidae) at Point Calimere, Tamil Nadu. J. Bombay Nat. Hist. Soc., 94: 56-63.

Pina, J.P. 1989. Breeding bird assemblages in eucalyptus plantations in Portugal. Ann. Zool. Fenn., 26: 287-290.

Prajapati, S., and Prajapati, R. 2012. "Observations on Roosting Habitat of Rose-ringed parakeet (Psittacula krameri)," Life Sciences Leaflets, 7: 56-62.

Proenca, V.M. Pereira, H.M., Guilherme, J. and Vicente, L. 2010. Plant and bird diversity in natural forests and in native and exotic plantations in NW Portugal. Acta Oecol., 36: 219-226.
Pyšek, P., Jarošík, V., Hulme, P.E., Pergl, J., Hejda, M., Schaffner, U. and Vila, M. 2012. A global assessment of invasive plant impacts on resident species, communities and ecosystems: the interaction of impact measures, invading species' traits and environment. Glob. Change Biol., 18: 1725-1737.

Qian, H., Ricklefs, R.E. and White, P.S. 2005. Beta diversity of angiosperms in temperate floras of eastern Asia and eastern North America. Ecol. Lett., 8: 15-22.

Sandhu, S.K. 1993. Ecological studies on the association of birds with trees with special reference to nest-site selection. Ph.D. dissertation.Punjab Agricultural University, Ludhiana, India.

Schirmel, J., Bundschuh, M., Entling, M.H., Kowarik, I. and Buchholz, S. 2016. Impacts of invasive plants on resident animals across ecosystems, taxa, and feeding types: a global assessment. Glob. Change Biol., 22: 594-603.

Sekercioglu, C.H. 2006. Increasing awareness of avian ecological function. Trends Ecol. Evolut., 21: 464-471.

Sethi, J. and Kumar, M. 2018. Nesting and breeding ecology of Asian pied starling Sturnus contra. J. Ento. Zoo. Stud., 6(1): 713-716.

Shvidenko, A., Barber, C. V. and Persson, R. 2005. Forest and woodland systems. In: Hassan, R, Scholes, R, Ash, N. (Eds.), Ecosystems and Human Well-being: Current State and Trends. 585-621. Island Press, Washington D C.

Tellería, J.L. and Galarza, A. 1990. Birdlife and landscape in northern Spain: the effect of exotic tree populations. Ardeola, 37: 229-245.

Ulrich, W. and Gotelli, N.J. 2007. Null model analysis of species nestedness patterns. Ecology, 88: 1824-1831.

Vila, M., Espinar, J.L., Hejda, M., Hulme, P.E., Jarosik, V., Maron, J.L., Pergl, J., Schaffner, U., Sun, Y. and Pysek, P. 2011. Ecological impacts of invasive alien species: a meta- analysis of their impact on species, Communities and ecosystem. Ecol. Lett., 14: 702-08.

Vyas, B.M. 2009. Breeding seasons and nest site selection of some selected urban birds of Visnagar city area and its vicinity, TAsian. J. Anim. Sci., 4: 88-90. (1).

Whelan, J.C., Sekercioglu, C.H. and Wenny, D.G. 2015. Why birds matter: from economic ornithology to ecosystem services. J. Field Ornithol., 156: 227-238

Zurita, G.A., Rey, N., Varela, D.M., Villagra, M. and Bellocq, M.I. 2006. Conversion of the Atlantic Forest into native and exotic tree plantations: Effects on bird communities from the local and regional perspectives Forest Ecology and Management 235: 164-173. 
